\title{
Physical properties, crystalline textures and $c$-axis fabrics of the Siple Dome (Antarctica) ice core
}

\author{
Anthony J. GOW, ${ }^{1}$ Debra MEESE ${ }^{1,2}$ \\ ${ }^{1}$ US Army Cold Regions Research and Engineering Laboratory, 72 Lyme Road, Hanover, New Hampshire 03755-1290, USA \\ ${ }^{2}$ Climate Change Institute, University of Maine, 303 Bryand Global Sciences Center, Orono, Maine 04469-5790, USA \\ E-mail: debra.meese@maine.edu
}

\begin{abstract}
The quality of the ice core from Siple Dome, West Antarctica, varied widely, with significant fracturing below $400 \mathrm{~m}$. Bubbly ice persisted to the ice-rock interface at $1004 \mathrm{~m}$ and constituted the brittle zone. The core has undergone minimal relaxation and has remained brittle and prone to fracturing more than 5 years after it was drilled. This behavior is attributed to unrelieved stresses from Kamb and Bindschadler Ice Streams (former Ice Streams C and D) flanking the dome. Melt layers were identified sporadically throughout the core, as were inclined layers tilted at angles that occasionally exceeded $10^{\circ}$. Structurally, the ice was characterized by extensive recrystallization including grain-size changes from $0.074 \mathrm{~cm}^{2}$ at $59 \mathrm{~m}$ to $>50 \mathrm{~cm}^{2}$ at $992 \mathrm{~m}$, and major transitions in c-axis fabrics. Unusual fabrics included vertical $c$-axis clusters superimposed on vertical girdles that may reflect vertical compression acting in conjunction with horizontal tension. The sudden appearance of a shear-type fabric at $\mathbf{7 0 0 - 8 0 0 ~ m ~ a p p e a r s ~ c l o s e l y ~ l i n k e d ~ t o ~ t h e ~ o c c u r r e n c e ~ o f ~ a b u n d a n t ~ t e p h r a ~ p a r t i c l e s ~}$ embedded in the ice. The occurrence of dispersed sediment in the bottom $2 \mathrm{~m}$ is attributed to freeze-on of basal meltwater.
\end{abstract}

\section{INTRODUCTION}

The principal objective of the Siple Dome (West Antarctica) drilling project was to obtain a high-resolution ice core to bedrock located $1004 \mathrm{~m}$ below the surface of the dome. The dome is situated at $81.65^{\circ} \mathrm{S}, 148.81^{\circ} \mathrm{W}$ on an east-westtrending ridge between Kamb and Bindschadler Ice Streams (former Ice Streams C and D) (Fig. 1), and reaches a maximum elevation of about $620 \mathrm{~m}$ a.s.l. Bedrock is located about $400 \mathrm{~m}$ below sea level directly beneath the dome. Analysis of shallow firn cores obtained prior to deep drilling by the Polar Ice Coring Office (PICO) indicates a current accumulation rate of $10-14 \mathrm{~cm}$ of ice per year. Ten-meter firn temperature measurements indicate a mean annual surface temperature of $-25^{\circ} \mathrm{C}$. A major reason for choosing Siple Dome as a drilling site was its coastal location where the ice would be thick enough to yield a core with a climatic record of at least $100 \mathrm{kyr}$. However, accurate interpretation of the geochemical records needed to evaluate paleoclimatic history of the Siple Dome core requires very careful evaluation of the physical and structural properties of the ice itself. For example, Gow and Williamson (1976), Dansgaard and others (1982) and Robin (1983) have demonstrated that significant blurring of the paleoclimatic record can result from discontinuities and inhomogeneous flow in the deeper parts of ice sheets. At the Greenland Ice Sheet Project 2 (GISP2) and Greenland Icecore Project (GRIP) sites, basal sections of both ice cores display evidence of significant stratigraphic distortion including inclined layering (up to $30^{\circ}$ ), boudinage and overturned folds (Gow and others, 1993, 1997; Taylor and others, 1993; Alley and others, 1995). However, based upon the essentially flat topography extending outwards for several kilometers beneath Siple Dome, significant stratigraphic disturbance in the basal ice is not expected.

A principal objective of this paper is to document the major physical and structural properties of the Siple Dome ice core. The studies included determination of the ice-core relaxation process based on repeat measurements of icecore densities; this process does not appear to follow the same course of change observed in the relaxation behavior of other deep cores from Antarctica and Greenland. Additional studies included evaluation of the forces driving crystal growth processes and $c$-axis fabric patterns as a function of depth in the Siple Dome ice core. These two property profiles reflect not only the dynamic situation of Siple Dome ice but also possible interaction between Siple Dome and Kamb and Bindschadler Ice Streams that flank it. Debris entrainment mechanisms based on consideration of the nature, disposition and concentration of debris in the

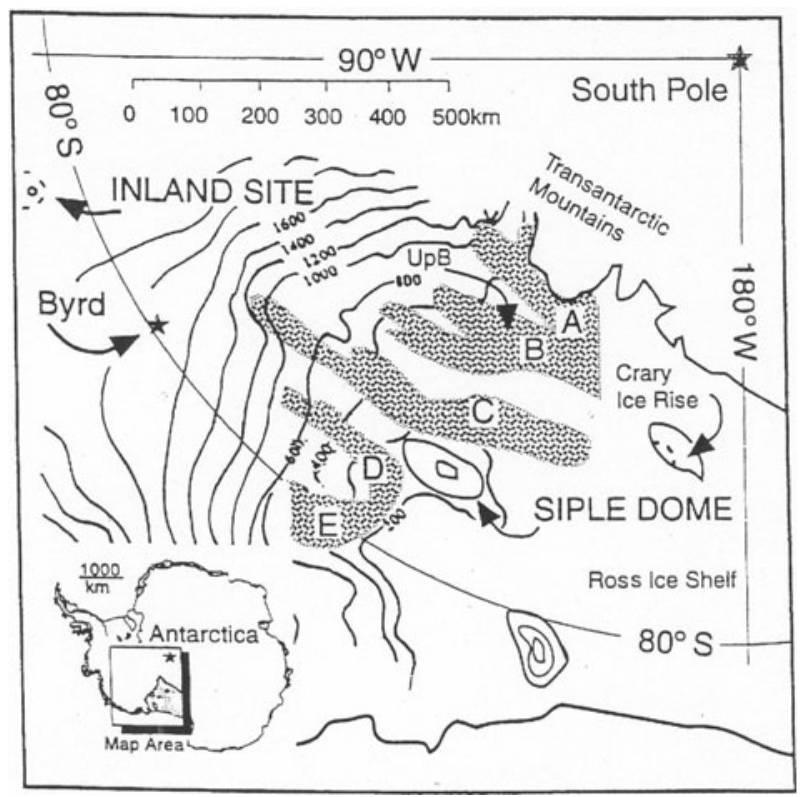

Fig. 1. Location map of Siple Dome and environs (modified from Alley and Whillans, 1991). 
basal ice, and variations in total gas content of the debrisbearing ice were also examined. Tephra deposition, indicative of active volcanism in Antarctica, was especially abundant between 700 and $800 \mathrm{~m}$ where the abrupt development of a strong horizontal shear-type fabric appears strongly linked to the widespread occurrence of dust-sized tephra particles embedded in the ice. Results of tephra studies, including detailed discussions of the timing and pattern of distribution of tephra deposition and the potential impact of the eruption and fallout of volcanic ash and dust on the climate and rheological characteristics of the ice at Siple Dome, are reported elsewhere (Gow and Meese, 2007). Results of earlier research conducted on hot-water cores from the summit and flank of Siple Dome in 1997/98 were presented by Gow and Engelhardt (2000).

\section{PHYSICAL PROPERTIES}

\section{Drilling procedures/mechanical condition of freshly drilled core}

Drilling of the PICO core at Siple Dome during 1997-99 was conducted with a cable-suspended electromechanical drill. The drill was essentially the same as that used to drill to bedrock beneath the summit of the Greenland ice sheet during GISP2. Butyl acetate was added to the hole to counteract the overburden pressure and prevent closure of the drillhole. Stresses in the ice, relieved when the superincumbent load of the overlying ice is removed by drilling, resulted in major changes in the mechanical condition of the core. Drilled cores, $13.2 \mathrm{~cm}$ in diameter, were in good to excellent condition through the top $350 \mathrm{~m}$, with many of the cores, averaging $2.5 \mathrm{~m}$ per run, being delivered to the surface in one unbroken piece. By $400 \mathrm{~m}$, substantially unbroken core was retrieved from about $75 \%$ of the drill runs, but the remaining $25 \%$ had undergone widespread fracturing. This fracturing increased in severity below $400 \mathrm{~m}$ and constituted the region known as the brittle zone, which persisted to the ice-bedrock interface $1004 \mathrm{~m}$ below the surface.

\section{Melt layers}

Melt layers were identified sporadically throughout the Siple Dome core and testify to extended periods when surface snow was subjected to temperatures above $0^{\circ} \mathrm{C}$. At least 20 melt layers were observed in the upper $500 \mathrm{~m}$. These included three melt events that were sufficiently severe to create lenses of ice 5-10 mm thick. Individual melt layers ranged in thickness from 1-2 $\mathrm{mm}$ to a maximum of $6 \mathrm{~mm}$. At least eight melt layers were identified between 500 and $800 \mathrm{~m}$ depth that also ranged in thickness from 1 to $2 \mathrm{~mm}$. However, the quality of core from below $800 \mathrm{~m}$ was so degraded by fracturing as to preclude any positive identification of melt events in this part of the Siple Dome ice core. For a discussion of the significance of the melt layers see Das (2003) and Das and Alley (2005).

\section{Inclined layers}

The presence of inclined layers or other signs of englacial disturbance at Siple Dome was investigated during light table examination of the core. Slight tilting of layers associated with annual layers was first observed between 432.60 and $432.70 \mathrm{~m}$ and continued with depth at intervals to $550.71-550.76 \mathrm{~m}$. Below this, short sequences of core exhibiting inclined layering with reversed dips began to make their appearance at 559.51-559.60 m. These tilted layers with reversed dips continued at intervals to nearly $800 \mathrm{~m}$ and were intermixed with inclined layers tilted at angles that occasionally exceeded $10^{\circ}$, indicating the possibility of large-scale folds. Such folding indicates that a continuous uninterrupted climate signal does not exist below these depths. Other signs of disturbance such as small folds or boudinage were not observed in the basal $200 \mathrm{~m}$ of ice at Siple Dome; however, the very badly fractured condition of these basal cores greatly lessened any chance of observing disturbed structure if it existed.

\section{Brittle core processing and the relaxation process}

Fracturing is a particular feature of ice in the brittle zone of all deep cores from Antarctica and Greenland. A major factor contributing to the intrinsic brittleness of ice cores in this zone is release of the confinement pressure that causes so-called relaxation stresses to exceed the intrinsic tensile strength of the cored ice. At Siple Dome this condition is reached at 300-400 m depth, which was why, at the end of the season's drilling, all core from below $394 \mathrm{~m}$ was retained in a storage trench to relax for 1 year before being shipped to the US National Ice Core Laboratory (NICL) in Denver, Colorado, in 2000 for general processing. Core from above $394 \mathrm{~m}$ that was not brittle was returned to the United States and processed at NICL during June and July 1999. On-site processing for this project was limited to measurements of density and thin-section preparation on freshly drilled cores. However, even these studies had to be curtailed at around $700 \mathrm{~m}$ because of the increasingly poor quality of the core and intense fracturing that occurred in the very brittle ice when attempting to prepare samples on the bandsaw (personal communication from J. Fitzpatrick, 1999).

Cores recovered from even moderate depths at Siple Dome are subject to relaxation, a process first documented in detail by Gow (1971) in regard to deep drill cores retrieved at Byrd Station, West Antarctica, in 1967/68. Relaxation manifests itself in a number of ways that include microcracking and fracturing, bubble decompression and dilation, and frequent splitting along basal planes of crystals intersecting pressurized air bubbles. An additional mechanism is exsolution of air previously converted in deeper parts of the ice dome to gas hydrates, which dissociate to form discrete bubble-like inclusions in the ice as it relaxes.

\section{Density measurements}

Relaxation entails a decrease in density, leading to a volume expansion of the ice that can be monitored by repeat density measurements. Densities of core pieces, 10-11 cm long, were measured by hydrostatic weighing in reagent grade isooctane (2-2-4 trimethylpentane). This technique (Butkovich, 1953) measures densities to $\pm 0.0003 \mathrm{Mg} \mathrm{m}^{-3}$ and has been used extensively on polar ice cores by Langway (1958a), Gow (1968, 1971) and Gow and others (1997). Initial measurements were made on freshly drilled core within a few hours of its retrieval from the drillhole. These measurements were performed at approximately $20 \mathrm{~m}$ intervals beginning at $60 \mathrm{~m}$, just below the firn/ice transition, and extending to $700 \mathrm{~m}$ before encountering very brittle core. A plot of density measurements from ice deeper than $100 \mathrm{~m}$ is presented in Figure 2. The inset diagram includes a density profile based on all data from the snow surface down.

The firn-ice transition, corresponding to pore close-off, occurs at around $54-55 \mathrm{~m}$ at a density of $0.830 \mathrm{Mg} \mathrm{m}^{-3}$. 
Thereafter, density increases progressively with depth, reaching a maximum temperature-corrected density of $0.9160 \mathrm{Mg} \mathrm{m}^{-3}$ at $700 \mathrm{~m}$. Densification occurs primarily in response to increasing overburden pressure, causing compression of entrapped air bubbles originally sealed off at the firn-ice transition. Thin-section measurements of bubble diameter, in conjunction with density-derived porosities, indicate that equalization of air-bubble pressure with ice load occurs around $300 \mathrm{~m}$ at an overburden pressure of 2.62.7 MPa. When applied to measurements of bubble concentrations in Siple Dome ice, the same technique yielded values of $180-210$ bubbles per cubic centimeter in cores from 60 to $600 \mathrm{~m}$. However, there is also evidence from thin-section observations that bubbles begin to decrease in concentration at about $600 \mathrm{~m}$, at which depth other bubblelike inclusions appear. These inclusions are attributed to the dissociation of gas hydrates originally formed by dissolution of pressurized atmospheric gases through bubble walls into the ice. Bubbly ice occurs without break to the bed at $1004 \mathrm{~m}$. Changes in air-bubble characteristics with increasing depth are shown in Figure 3.

\section{Relaxation characteristics}

The relaxation characteristics of Siple Dome ice cores are presented in Figure 4. This dataset is based on the differences in density between measured samples of freshly drilled core and the same samples measured 5 years later. As noted earlier, measurements on freshly cored ice at the drill site were terminated at $702 \mathrm{~m}$ because of the very fragile and brittle nature of the core. Density measurements on samples of this deeper ice were not made until 5 years later. Relaxation characteristics of the deeper ice were obtained by comparing the densities of samples from 702-1004 m, suitably corrected for measured in situ temperatures, with those obtained by extrapolation of the depth-density profile below $702 \mathrm{~m}$ in Figure 2.

Except for ice from 700-800 m, the Siple Dome core has undergone minimal relaxation in the 5 years since it was drilled in 1997-99. By contrast, much more rapid relaxation, accompanied by a significant decrease in brittleness, was observed at the other drilling sites in Antarctica and Greenland where monitoring of the relaxation process was conducted, for example at Byrd Station (Gow, 1971) and at GISP2 (Gow and others, 1997). This behavior is demonstrated in Figure 4. Relaxation levels measured on Siple Dome cores 5 years after they were drilled were achieved at Byrd after only 16 months; this was followed by further significant relaxation at Byrd at the end of 27 months. Furthermore, cores from Byrd had become sufficiently 'ductile', within 6-9 months after drilling that they could be cut with a bandsaw without fracturing. However, the Siple Dome core has remained brittle and prone to fracturing during processing more than 5 years after it was drilled.

Ice from $700-800 \mathrm{~m}$ has undergone appreciably more relaxation than ice above or below this zone. This ice is much finer-grained, and also features a very strong vertical $c$-axis fabric in which the component crystals have been subject to extensive cleavage cracking (a form of latticecontrolled microcracking) along the basal glide planes of the crystals. Microcracking of this kind is a very effective way to relieve stress in crystals exhibiting a strong $c$-axis vertical orientation; the extensive nature of this microcracking, which is readily observed in hand-held cores, also accounts for the enhanced level of relaxation in the zone $700-800 \mathrm{~m}$.

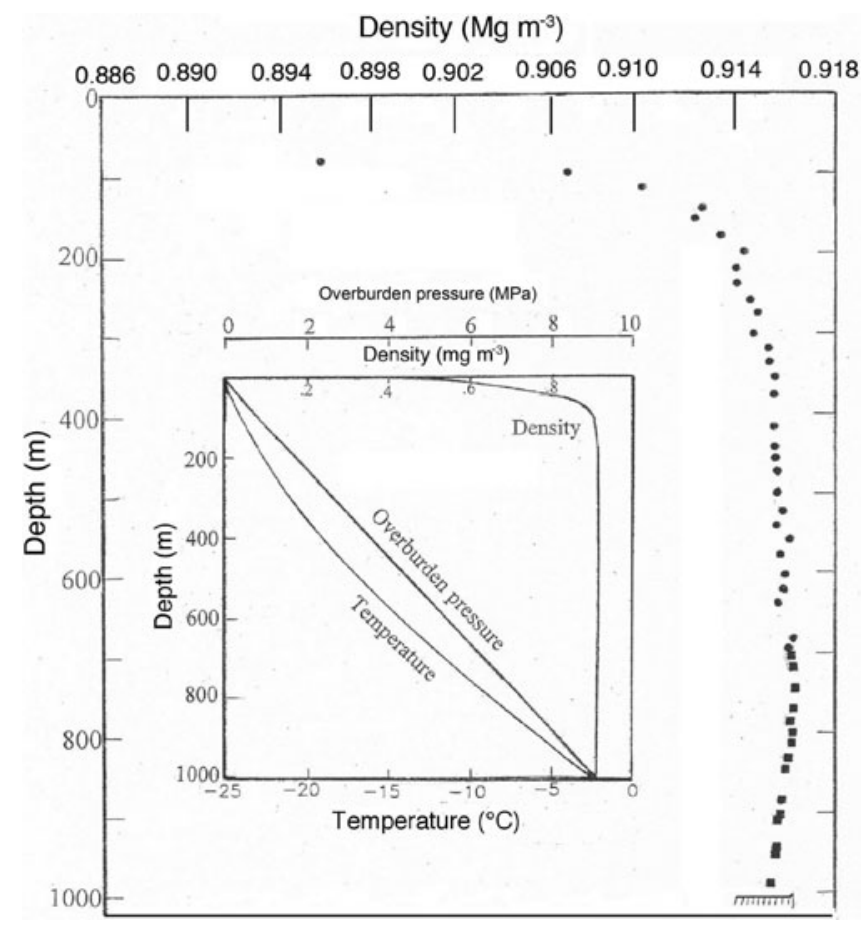

Fig. 2. Plot of density measurements vs depth in cores from Siple Dome. Densities measured on freshly drilled core from just below the firn-ice transition to $702 \mathrm{~m}$ are indicated by solid circles. Below $702 \mathrm{~m}$ the ice was too brittle to process on site. These densities, indicated by filled squares, were based in part on measurements of slightly relaxed ice samples in conjunction with extrapolation of the density profile from above $702 \mathrm{~m}$. All densities were corrected for in situ temperature measured in the drillhole by Engelhardt (2004). Inset diagram includes a complete density profile together with ice overburden and temperature profiles at Siple Dome.

The generally poor condition of much of the Siple Dome core at the time it was drilled has been attributed largely to defects in the drilling technique (e.g. binding in the core barrel). However, the fact that the core has remained brittle long after it was drilled suggests that factors other than defective drilling techniques have contributed to its continued brittleness. One such factor may be unrelieved residual stresses related to the intimate contact of Siple Dome with Kamb and Bindschadler Ice Streams located on either side of the dome. Such intimate contact including shear margin migration likely led to complex ice dynamics at Siple Dome and the subsequent continued brittleness of the core.

Relaxation characteristics of the Siple Dome core depart radically from those observed in cores obtained by hot-water drilling during the 1997/98 field season at three sites in close proximity to Siple Dome (Gow and Englehardt, 2000). One of these sites was drilled in the immediate vicinity of the PICO drillhole, another located on the true summit of Siple Dome, about $400 \mathrm{~m}$ from the PICO drill site, and a third situated on the flank about 8-9 km from the summit. When first removed from the core barrel, freshly drilled hot-water cores exhibited minimal fracturing. The cores were then retained at each of the drilling sites for several days while exposed to elevated surface air temperatures (one or two degrees below $0^{\circ} \mathrm{C}$ ), before being transferred to a storage trench where temperatures hovered around $-17^{\circ} \mathrm{C}$. During the time the cores were retained at the surface, they underwent a rapid relaxation that manifested itself in a number of ways including microcracking in the shallower 


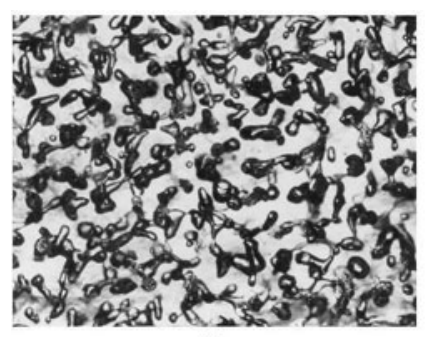

$59 \mathrm{~m}$

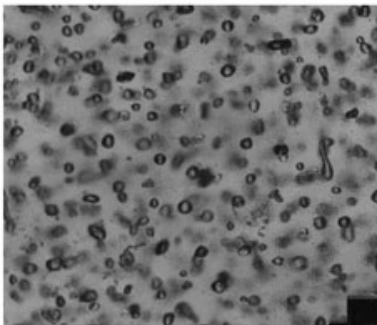

$104 \mathrm{~m}$

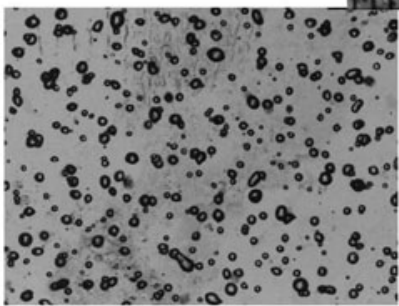

$140 \mathrm{~m}$

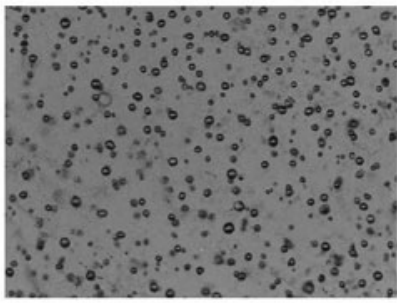

$205 \mathrm{~m}$

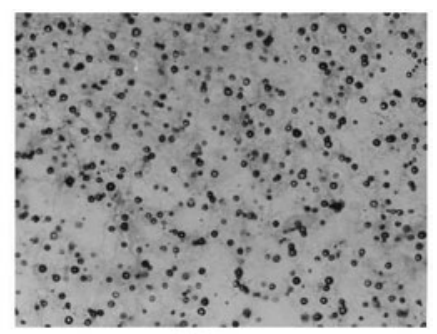

$402 \mathrm{~m}$

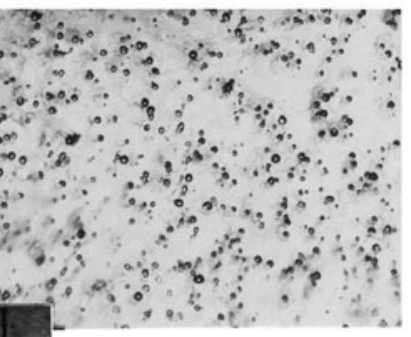

$507 \mathrm{~m}$

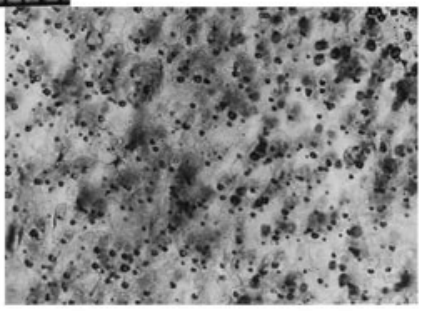

$605 \mathrm{~m}$

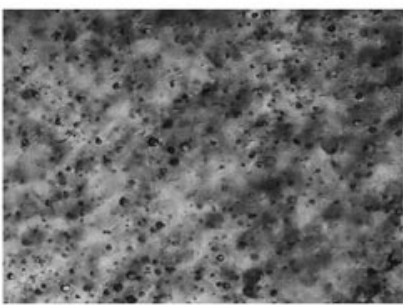

$988 \mathrm{~m}$

Fig. 3. Air-bubble change with increasing depth of burial in Siple Dome ice cores. Note rapid transition from largely tubular bubbles just below pore close-off at $59 \mathrm{~m}$ to substantially spherical bubbles between 104 and $140 \mathrm{~m}$. Bubble sections from 205 to $507 \mathrm{~m}$ were obtained from samples that had undergone minimal relaxation. Bubbles persisted to the bed at Siple Dome accompanied by odd-shaped inclusions attributed to gas hydrate dissociation in slightly relaxed ice core in samples from 605 and $988 \mathrm{~m}$. Smallest scale subdivisions measure $1 \mathrm{~mm}$.

cores (down to about $400 \mathrm{~m}$ ), and widespread fracturing beginning at around $500 \mathrm{~m}$ and continuing to the bottom of the ice dome. This mechanical conditioning of the ice at all levels appeared to have substantially stabilized prior to moving the cores to the storage trench.

The rapidity with which relaxation occurred in these thermally drilled cores at Siple Dome is attributed to thermal effects associated with hot-water drilling but was also accelerated by the thermal conditioning of cores exposed to elevated surface air temperatures for several days. Following this short-term stabilization of the relaxation process, cores could be readily processed without further fracturing. Volume expansion of the ice associated with this relaxation of the hot-water cores ranged from $0.3 \%$ at around $300 \mathrm{~m}$ to nearly $3 \%$ in the deepest cores which, as indicated in Table 1 (from Gow and Engelhardt, 2000), is nearly an order of magnitude greater than observed in the electromechanically drilled Siple Dome core (Fig. 4). Furthermore, comparison of the crystalline textures and $c$-axis fabrics of both the hot-water cores and mechanically drilled core has not revealed any significant differences between them. In light of these observations, it would have been interesting to determine whether exposing pieces of the Siple Dome core to elevated temperatures for several days to a month would have accelerated the rate of relaxation sufficiently to reduce brittleness to a level that allowed processing of the ice without undue fracturing.

\section{CRYSTALLINE TEXTURES}

\section{Thin-section preparation}

Crystal structure (texture and fabric) studies of the Siple Dome core were performed on thin sections prepared from 5-10 mm thick samples cut horizontally, that is perpendicular to the vertical axis of the core. These thick-section samples were affixed to glass slides with cyanoacrylate glue and then sliced to $1 \mathrm{~mm}$ or less on a microtome. Subsequent examination of thin sections was carried out following 


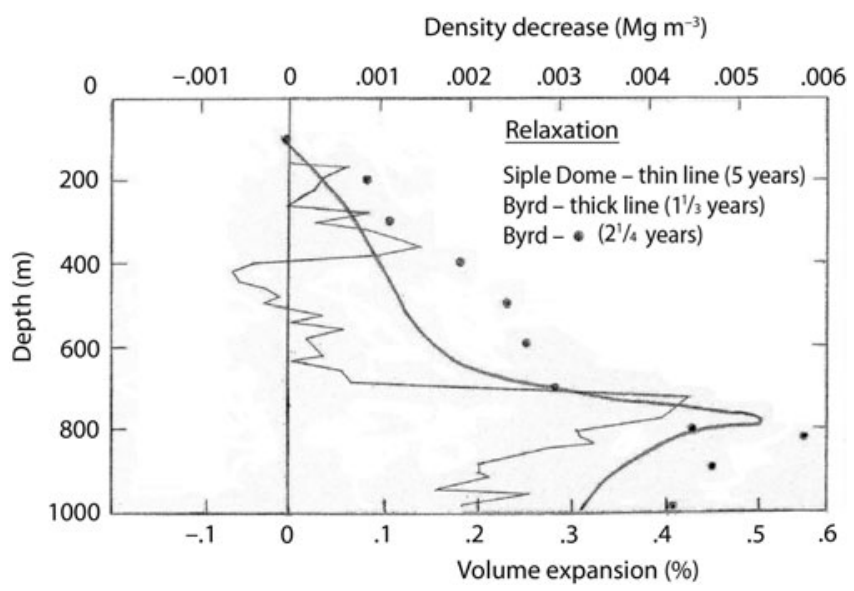

Fig. 4. Relaxation characteristics (density change with time) of Siple Dome ice cores. Repeat measurements made on the Siple Dome core samples 5 years after they were drilled are compared with results obtained on samples of the Byrd core 16 and 27 months following recovery of the core. Despite the highly brittle nature of the Siple Dome core, it has undergone significantly less relaxation than the Byrd core for reasons explained in the text.

techniques described in Rigsby (1955, 1960), Langway (1958b) and Gow (1970). Thin sections were then photographed between crossed polarizers to assist in identifying individual crystals and to aid in recording $c$-axis measurements with the Rigsby stage. All measurements were made at $-10^{\circ} \mathrm{C}$, and the thin sections themselves were stored at $-30^{\circ} \mathrm{C}$ to minimize both sublimation and possible changes in crystalline structure.

\section{Crystal size measurements}

Crystal sizes were determined from measurements of the number of crystals in given areas of thin-section photographs ranging in size from 72 to $80 \mathrm{~cm}^{2}$. A small correction was applied to crystal counts to compensate for those crystals only partly contained within the area boundaries. This correction is minimal for the large number of crystals measured in fine-grained ice. However, it becomes increasingly difficult to apply this correction to coarse-grained ice when the number of crystals decreases to less than ten and crystals become increasingly interlocked. The number of crystals counted ranged from nearly 500 at $100 \mathrm{~m}$ depth to approximately 50 at $361 \mathrm{~m}$. Further, significant increases in crystal size between 361 and $686 \mathrm{~m}$ depth reduced grainsize counts to between 20 and 10 . This was followed by a section of core, $700-800 \mathrm{~m}$, that underwent a dramatically abrupt decrease in grain size leading to a substantial increase in the number of crystals counted (84-193). Just as abruptly, the size of crystals between 800 and 1000 m depth increased rapidly and the number of grains counted within the given area of a section decreased from around 10 to less than 2 .

\section{Crystal size variation}

Variations of crystal size with depth at Siple Dome are presented in Figure $5 \mathrm{a}$ and $\mathrm{b}$ (adapted from Gow and Engelhardt, 2000) and include grain-size data from a hotwater core drilled at the summit site in 1997-98 and results of measurements made on the Siple Dome (PICO) core drilled in 1997-99. Also included for comparison are the crystal size data obtained by Gow and Williamson (1976) on the Byrd Station core (Fig. 5a).
Table 1. Relaxation characteristics of Siple Dome hot-water cores (from Gow and Engelhardt, 2000). In situ density values were calculated on the basis of a bubble close-off porosity of 0.098 at $50 \mathrm{~m}$ depth and equalization of the entrapped air bubble and the absolute overburden pressures at $300 \mathrm{~m}$

\begin{tabular}{lccc}
\hline Depth & $\begin{array}{c}\text { Calculated } \\
\text { in situ density } \\
\mathrm{Mg} \mathrm{m}^{-3}\end{array}$ & $\begin{array}{c}\text { Measured } \\
\text { density }\end{array}$ & Relaxation \\
\hline Summit core & & & \\
303 & 0.9158 & & \\
402 & 0.9166 & 0.9135 & \\
505 & 0.9168 & 0.9095 & 0.25 \\
605 & 0.9167 & 0.9009 & 0.76 \\
676 & 0.9166 & 0.9009 & 1.73 \\
989 & 0.9158 & 0.8940 & 1.72 \\
& & 0.8893 & 2.47 \\
Flank core & & & 2.89 \\
302 & 0.9158 & 0.9132 & \\
404 & 0.9166 & 0.9134 & 0.28 \\
503 & 0.9168 & 0.8996 & 1.88 \\
603 & 0.9167 & 0.8982 & 2.02 \\
703 & 0.9166 & 0.8960 & 2.25 \\
809 & 0.9164 & 0.9014 & 1.64 \\
901 & 0.9162 & 0.8978 & 2.01 \\
972 & 0.9160 & 0.8928 & 2.53 \\
977 & 0.9159 & 0.8947 & 2.32 \\
& & & \\
\hline
\end{tabular}

Firn at Siple Dome transforms into ice at around $55 \mathrm{~m}$; at $59 \mathrm{~m}$ a mean crystal cross-sectional area of $0.074 \mathrm{~cm}^{2}$ was measured in the PICO core. By $99 \mathrm{~m}$ the mean grain size had increased to $0.12 \mathrm{~cm}^{2}$. Grain size continued to increase linearly with depth down to at least $201 \mathrm{~m}$ where the mean crystal cross-section measured $0.28 \mathrm{~cm}^{2}$. Over this depth interval, the crystal structure exhibited a mosaic-type texture of essentially equidimensional crystals with sharply defined grain boundaries (see Fig. 6). The region between 59 and $201 \mathrm{~m}$ is contained within the zone of normal grain growth (no grain-size measurements were made in the firn above $55 \mathrm{~m})$, and may extend to around $300 \mathrm{~m}$. A linear growth rate of $0.019 \mathrm{~mm}^{2} \mathrm{a}^{-1}$, observed between 59 and $201 \mathrm{~m}$, is somewhat greater than that expected for an in situ temperature of -25 to $-23^{\circ} \mathrm{C}$ measured in the top $200 \mathrm{~m}$ at Siple Dome. A somewhat smaller growth rate of around $0.012 \mathrm{~mm}^{2} \mathrm{a}^{-1}$ would have been anticipated based on Paterson's growth-rate-temperature-dependence plot (Paterson, 1994). The moderately increased rate of grain growth observed in the normal grain growth regime at Siple Dome could indicate an enhanced level of stress in this zone. DiPrinzio and others (2005) have estimated changes in the fabric and texture of the ice between 200 and $685 \mathrm{~m}$ that they attribute to dynamic recrystallization. This in itself would indicate that significant deformation exists in the upper levels of ice at Siple Dome.

A large increase in crystal size to $0.64 \mathrm{~cm}^{2}$ at $221 \mathrm{~m}$ was also accompanied by a significant change in texture, from crystals with sharply defined boundaries above $201 \mathrm{~m}$ to crystals that now possessed sutured outlines. This was followed by a significant decrease in grain size at $261 \mathrm{~m}$ to $0.39 \mathrm{~cm}^{2}$ where many of the crystals exhibited subvertical $c$-axis orientations and much evidence of optical strain (undulose extinction), possibly indicating some slight bending 
a
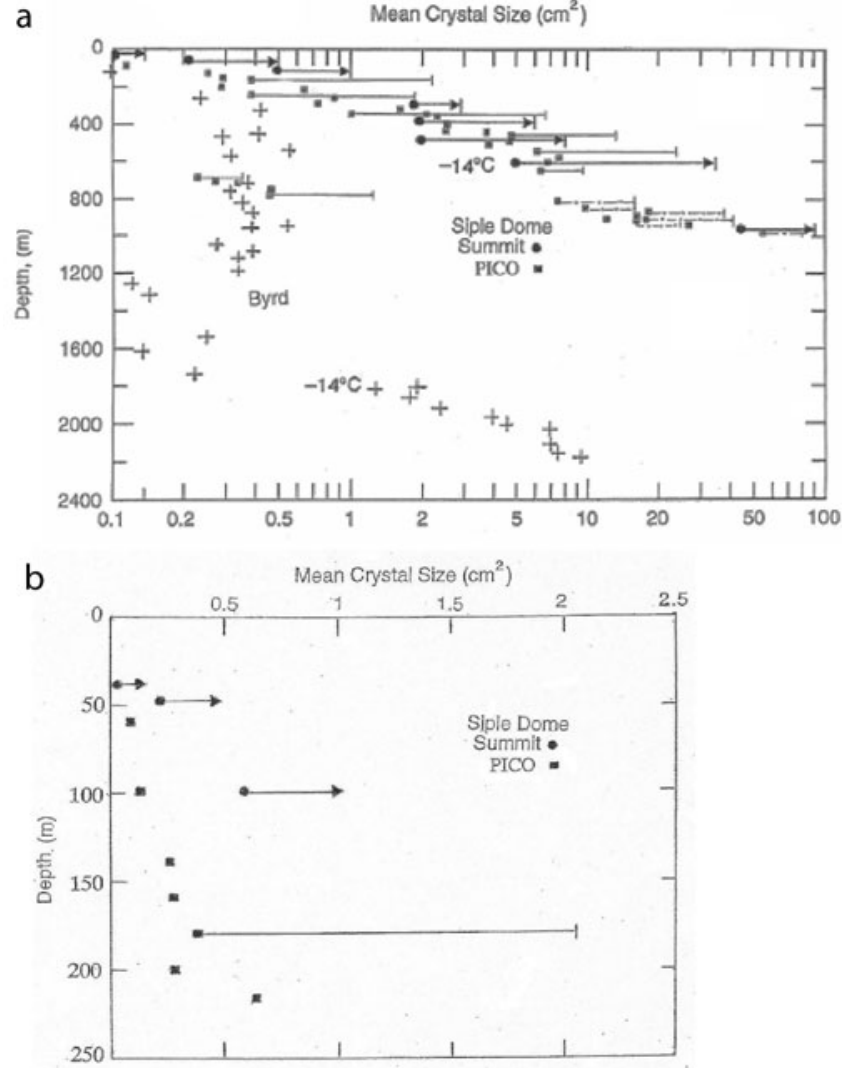

Fig. 5. (a) Mean crystal size (cross-sectional area) vs depth at Siple Dome. Data are plotted on a logarithmic scale to accommodate the very large range of crystal sizes measured. Comparisons with datasets from the Summit hot-water core drilled in close proximity to the PICO drilled Siple Dome core and from the Byrd core are included. The largest crystal at any particular depth in the Summit core is indicated by an arrow at the end of the solid line. The termination of a dotted line in the deepest part of the PICO core designates the largest crystal measured, but with its grain boundaries only partially contained within the thin section. (b) Expanded plot of crystal size data (linear scale) for the top $250 \mathrm{~m}$ at Siple Dome.

or buckling of the basal glide planes of the crystals as they rotated in response to increasing uniaxial vertical compression.

Ice below $261 \mathrm{~m}$ was marked by sharp increases in the size of crystals that exceeded $1.0 \mathrm{~cm}^{2}$ by $341 \mathrm{~m}$ and $2.0 \mathrm{~cm}^{2}$ by $382 \mathrm{~m}$, followed by near-constant values of around $2.5 \mathrm{~cm}^{2}$ between 400 and $445 \mathrm{~m}$. Crystal sizes further increased to between 3.50 and $5.0 \mathrm{~cm}^{2}$ by $540 \mathrm{~m}$, followed by major changes in grain size to between 6 and nearly $8 \mathrm{~cm}^{2}$ over the interval $560-586 \mathrm{~m}$. Sutured crystal textures persisted from $221 \mathrm{~m}$, when first encountered in Siple Dome ice, to $686 \mathrm{~m}$. All thin sections from this depth range contained crystals that were intersected two or more times in the same section. This multiple cutting of the same crystal in a single thin section yields textures akin to a threedimensional jigsaw puzzle that renders grain-size measurements in this kind of ice virtually meaningless, except to indicate trends in crystal growth.

As indicated in Figure 5, the grain-size changes observed in the Siple Dome core, down to at least $700 \mathrm{~m}$ depth, track closely those measured on the Summit (hot-water) core. This indicates that hot-water drilling per se has not affected crystalline textures in Siple Dome ice. An abrupt 30- to
15 -fold decrease in grain size, beginning at $703 \mathrm{~m}$ $\left(0.23 \mathrm{~cm}^{2}\right)$ and persisting to at least $790 \mathrm{~m}\left(0.47 \mathrm{~cm}^{2}\right)$ in the Siple Dome core, was not observed in the Summit (hotwater) core because core was not collected at these depths.

The zone of fine-grained ice in the Siple Dome core occurred coincidentally with sustained deposition of volcanic ash, particles which may have contributed initially to the much reduced grain size by anchoring the crystal boundaries. Expectations of finding volcanic ash in Siple Dome core were based on the documented existence of widespread deposition of tephra in the Byrd core (Gow and Williamson, 1971). Given its relative proximity to Byrd Station, it was anticipated that similar deposits of volcanic ash and dust would be found in ice of comparable age at Siple Dome. Using the age-depth model of Nereson and others (1996) for Siple Dome, Gow and Engelhardt (2000) accurately predicted that tephra coeval with that at Byrd should be concentrated in ice at $700-800 \mathrm{~m}$. While the abrupt reduction in grain size in ice from 700 and $800 \mathrm{~m}$ is likely due to tephra particles initially inhibiting grain growth in the upper levels of ice at Siple Dome, the widespread occurrence of undulose extinction in conjunction with the fragmented appearance of many of the crystals suggests that incorporation of tephra particles has ultimately led to significant changes in the rheological properties of finegrained ice.

By $820 \mathrm{~m}$ the crystalline texture of Siple Dome ice had transformed from very fine-grained, $0.47 \mathrm{~cm}^{2}$ at $790 \mathrm{~m}$, to very coarse-grained, $7.39 \mathrm{~cm}^{2}$ at $820 \mathrm{~m}$. This latter grain size is very similar to that measured between 560 and $686 \mathrm{~m}$ just prior to the sudden transition to fine-grained ice first encountered at $703 \mathrm{~m}$. Average grain sizes, as best as they could be measured, increased progressively from $9.66 \mathrm{~cm}^{2}$ at $848 \mathrm{~m}$ to greater than $50 \mathrm{~cm}^{2}$ at $992 \mathrm{~m}$, within $12 \mathrm{~m}$ of the ice-rock interface. Interlocked textures predominate, including repeated sectioning of individual crystals as first observed in the upper layers of the ice dome at around $221 \mathrm{~m}$. Crystals in ice from below $900 \mathrm{~m}$ often exceeded the dimensions of the $13 \mathrm{~cm}$ diameter core. These included zones of very large crystals exhibiting etched grain boundaries on the outer surface of a core, including several growing side by side with individual cross-sections measuring at least $130 \mathrm{~cm}^{2}$.

\section{CRYSTALLINE FABRICS}

\section{Fabric patterns in polar glacier ice}

Ice under stress deforms and it is the interplay of stress and deformation that determines the nature of $c$-axis fabrics in glacier ice. It is generally agreed that rotation of crystallographic $c$ axes by glide along the basal planes of crystals is the predominant mechanism by which preferred orientations evolve in glacier ice. This is tantamount to Rigsby's (1960) statement that proper orientation of the crystal in order to glide on the basal plane is very important in the flow of polar glacier ice'. This process applies equally well to rotations of $c$ axes either into a girdle fabric (a planar distribution of $c$ axes) or into a broad clustering of $c$ axes about a given axis. The nature of the stress in glaciers, including valley glaciers, ice sheets and ice domes, controls the nature of the fabric pattern. It is the cumulative strain to which the glacier ice is subjected, however, that determines the strength of the $c$-axis fabric. The formation of strong girdle fabrics in which the $c$ axes are uniformly distributed within a great circle 


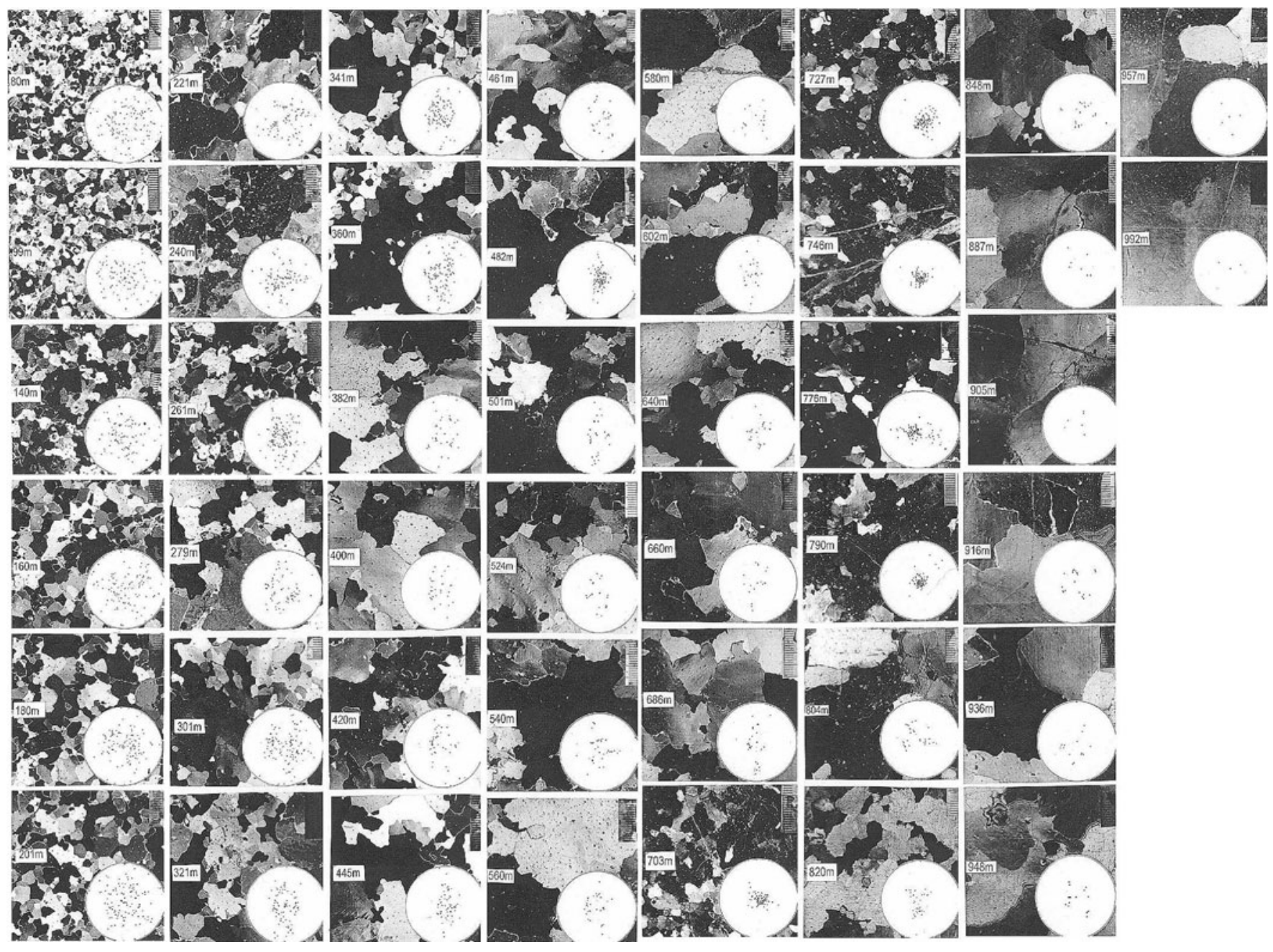

Fig. 6. Thin sections photographed between crossed polarizers, and their corresponding point scatter c-axis fabrics from representative depths in the Siple Dome ice core. Smallest subdivisions in scales in the top right corner of each thin-section photograph measure $1 \mathrm{~mm}$.

(generally vertical in ice sheets) is attributed to ice undergoing deformation in uniaxial longitudinal extension or tension in which the tensile axis is located normal to the girdle (Fujita and others, 1987; Alley, 1988; Lipenkov and others, 1989; Wang and others, 2003). The formation of a broad single-maximum fabric is usually attributed to ice subjected to deformation under uniaxial vertical compression (Azuma and Higashi, 1985; Alley, 1988; Gow and others, 1997; Thorsteinsson and others, 1997) or, in the case of a very tight vertical clustering of $c$ axes, to deformation governed by strong horizontal shear (Gow and Williamson, 1976; Gow and others, 1997). According to Wang and others (2002), an elongated single maximum can form when deformation is dominated by pure shear.

Rigsby (1955) was perhaps the first to relate the strength of the $c$-axis fabric of glacier ice to the level or intensity of deformation to which it is subjected. This situation applied in particular to very strong single-maximum fabrics that Rigsby observed forming perpendicular to foliation planes (planes of inferred shearing) in Greenland glacier ice. Additionally, Rigsby (1955) appears to have been among the first to recognize that recrystallization of glacial ice under high temperatures or melting conditions can lead to large increases in the size of crystals and associated significant fabric changes. This has since been amply demonstrated in Antarctic and Greenland ice subject to elevated temperatures in basal and near-basal sections of these ice sheets (Gow and Williamson, 1976; Gow and others, 1997; Thorsteinsson and others, 1997).

Apart from potential complications to the paleoclimate record, acknowledgement of the existence of widespread crystal anisotropy in polar ice sheets is critical to our understanding of the mechanics of ice flow and is especially pertinent to the whole topic of ice-sheet modeling including evaluation of the assumptions upon which much of the modeling is based.

\section{c-axis fabric measurements: techniques}

As indicated above, all $c$-axis fabric measurements were made with the manually operated four-axis Rigsby stage. A total of 45 horizontal fabric sections from representative depths in the Siple Dome core were analyzed on the Rigsby stage, which in recent years has been supplanted by a variety of computerized ice-fabric analyzers (e.g. Azuma and others, 1999; Wang and Azuma, 1999; Wang and others, 2002, 2003; Wilen and others, 2003). These instruments can measure $c$-axis orientations of very large numbers of crystals much more rapidly than could ever be accomplished on a Rigsby stage. Additionally, automated fabric analyzers can simultaneously yield comprehensive datasets on the size, shape and nearest-neighbor relationships of the crystals. The $c$-axis fabric patterns obtained with either type of instrument 
have been found to be essentially identical provided the number of crystals analyzed is statistically significant (Wilen, 2000). Statistically, the number should depend on the strength of the fabric, with a greater number of crystals needing to be measured in a randomly oriented fabric than one exhibiting either a girdle or an axial pattern of preferred $c$-axis orientation. It is generally agreed that around 200 $c$-axis measurements should suffice for any individual sample of ice exhibiting a random fabric or small deviations from randomness. Much less than 200 measurements should normally suffice for ice displaying strong $c$-axis fabrics.

The total number of $c$ axes measured in horizontal sections of the Siple Dome ice core exceeded 3000. The bulk of these measurements were confined to thin sections from the topmost $800 \mathrm{~m}$ of the ice core. The bottom $200 \mathrm{~m}$ is dominated by exceedingly large crystals, which limits the number of crystals in a single section, usually to too few to yield statistically significant results other than to indicate fabric trends. The large crystals, severe fractures and enduring brittleness in the deepest ice at Siple Dome hindered or even prevented the maintenance of core continuity needed for multiple sectioning of azimuthally oriented samples. Only at two depths below $900 \mathrm{~m}$ was it possible to prepare two vertical sections with the same relative orientation. In these sections, measured $c$-axis orientations were rotated into the horizontal plane to ensure conformity with $c$-axis measurements made on the horizontal thin sections.

\section{$c$-axis fabric profile at Siple Dome}

Thin-section photographs and associated $c$-axis fabrics of the Siple Dome core are presented in Figure 6. All fabric diagrams except two are based on equal-area (Schmidt-net) projections of $c$ axes measured in horizontal thin sections. The exceptions are two diagrams from 916 and 948 m, where paired vertical sections were used and the $c$-axis measurements subsequently rotated into the horizontal plane. The center of each fabric diagram coincides in all cases with the vertical axis of the core. As clearly demonstrated in Figure 6, changes in the texture of the ice at Siple Dome were accompanied by significant changes in aggregate $c$-axis orientation. At $60 \mathrm{~m}$ depth, ice from directly below the firnice transition at Siple Dome featured a random fabric, which was still in evidence at $80 \mathrm{~m}$. However, by $99 \mathrm{~m}$, signs of a broad vertical clustering of $c$ axes begin to appear and this trend is maintained and somewhat strengthened to at least $261 \mathrm{~m}$ depth. Such broad clustering of the $c$ axes, coupled with significant changes in the shapes and sizes of crystals that are clearly discernible in the thin-section photographs in Figure 6 , is consistent with a deformational process dominated by rotation of the $c$ axes towards the axis of vertical compression. As suggested earlier, the diminished grain size observed at $261 \mathrm{~m}$ together with significantly increased clustering of the $c$ axes and widespread undulose extinction of the crystals might indicate the onset of enhanced deformation associated with rotation and bending of basal glide planes of crystals under uniaxial vertical compression.

Some indications of a change in $c$-axis orientation to a girdle-like fabric are evident in sections from 261 to $321 \mathrm{~m}$. This trend towards a vertical girdle orientation appears firmly established by $360 \mathrm{~m}$ and generally persisted to at least $686 \mathrm{~m}$, though in most sections the girdle was somewhat incomplete, and in a number of cases is replaced by a redistribution of $c$ axes into three or four localized maxima, indicative of migration recrystallization. Between 686 and $703 \mathrm{~m}$ a very abrupt change in c-axis fabric that persisted to around $800 \mathrm{~m}$ depth occurred coincidentally with sustained deposition of volcanic ash (Gow and Meese, http://nsidc.org/data/nsidc-0128.html). This fabric, characterized by a very tight clustering of the $c$ axes about the vertical, is attributed to deformation now dominated by strong horizontal shear. Virtually identical texture (finegrained) and single pole fabrics, also attributed to horizontal shearing, have been observed at Byrd (Gow and Williamson, 1976) and at GISP2 (Gow and others, 1997). At Byrd, the very strong single pole fabric also occurs coincidentally with the onset and near termination of tephra deposition between 1300 and $1800 \mathrm{~m}$ (Gow and Williamson, 1971). At Siple Dome, the onset of very tight vertical clustering of $c$ axes between 686 and $703 \mathrm{~m}$ and its continuation to $790 \mathrm{~m}$ also coincides with a sudden increase in $p$-wave velocity to values exceeding $4000 \mathrm{~m} \mathrm{~s}^{-1}$ measured downhole (personal communication from G. Lamorey, 2000).

The very abrupt transition or flip-flop between two highly contrasted $c$-axis fabric patterns at around $700 \mathrm{~m}$ at Siple Dome not only reflects an abrupt change in the nature of the stress-strain field, it also signals a major change in the rheological properties of the ice. No such abrupt change in texture or fabric has been observed in cores from other ice dome sites, for example, Dome F (Azuma and others, 1999) or Dome C (Wang and others, 2003) in East Antarctica where the ice is approximately three times thicker than at Siple Dome. The potential importance of widespread incorporation of volcanic particles on the rheological properties of ice from $700-800 \mathrm{~m}$ at Siple Dome is discussed in greater detail by Gow and Meese (2007).

A very abrupt change back to coarse-grained ice occurs between 790 and $803 \mathrm{~m}$, as is evident in the thin-section photographs in Figure 6 . The onset of rapid crystal enlargement at $803 \mathrm{~m}$ occurs at -8 to $-9^{\circ} \mathrm{C}$ and is attributed to a form of dynamic recrystallization, also termed migration recrystallization by Duval and Castelnau (1995) and De La Chapelle and others (1998). Migration recrystallization involves both the nucleation and growth of strain-free grains at the expense of plastically deformed grains of the same material. Excess energy stored in the grains provides the driving force for this kind of recrystallization.

This extensive recrystallization to very coarse-grained ice, especially below $900 \mathrm{~m}$ at Siple Dome, was also accompanied by a marked change in fabric to a dispersed or multi-maximum distribution of $c$ axes about the vertical. Age, accumulated strain and elevated temperatures rather than any drastic change in stress level are considered major factors driving this growth of very large crystals. The rapid increase in the size of crystals in ice as it approaches the bed seriously impacts the number of $c$ axes that can be measured in a single or even two or three oriented thin sections. In ice from $848 \mathrm{~m}$ depth, the number of crystal $c$ axes measured was sufficient to reveal the true multimaximum nature of the fabric. This fabric pattern is also typical of coarse-grained ice that has undergone migration recrystallization at elevated temperatures in basal layers at Byrd Station (Gow and Williamson, 1976), GISP2 (Gow and others, 1997) and possibly at GRIP (Thorsteinsson and others, 1997). In ice deeper than $848 \mathrm{~m}$ with fewer than seven crystals in a single thin section, the statistical significance of the $c$-axis measurements is non-determinable. The badly fractured condition of cores from the deeper 
ice at Siple Dome greatly reduces the chances of preparing additional sections with the same relative orientation over an extended length of core. However, at two depths (916 and $948 \mathrm{~m}$ ) in the basal ice at Siple Dome, the core remained sufficiently intact to allow preparation of two vertical sections at each depth while still retaining the same relative orientation. Ice at both depths clearly reveals the multi-maximum fabric typical of coarse-grained dynamically recrystallized ice. The onset of migration recrystallization may have occurred somewhat above $803 \mathrm{~m}$. The marked increase in grain size beginning at $602 \mathrm{~m}$ may signal the early onset of migration recrystallization at Siple Dome where the in situ ice temperatures had risen to $-13^{\circ} \mathrm{C}$, the temperature at which migration recrystallization is initiated in deep ice at Byrd, GISP2 and less certainly at GRIP. This implies that deformation immediately prior to $602 \mathrm{~m}$ had reached a level sufficient to initiate nucleation and subsequent recrystallization to at least $686 \mathrm{~m}$ depth. Though ice between 602 and $686 \mathrm{~m}$ generally retains a vertical girdle fabric, conversion to a multi-maximum fabric or ring-like small circle distribution of $c$ axes about the vertical appears to have occurred at $640 \mathrm{~m}$ depth in both our and DiPrinzio and others' (2005) fabric profiles. Whether or not migration recrystallization is occurring between 602 and $686 \mathrm{~m}$ is still an open question. According to DiPrinzio and others (2005), evidence of dynamic (migration) recrystallization, involving the nucleation and growth of new grains in place of grains that existed prior to recrystallization, is observed between 200 and $685 \mathrm{~m}$ at Siple Dome. Englacial temperatures at Siple Dome increase from $-23^{\circ} \mathrm{C}$ at $200 \mathrm{~m}$ to $-13^{\circ} \mathrm{C}$ at $600 \mathrm{~m}$ (Engelhardt, 2004). Migration recrystallization is observed to occur in the basal parts of polar ice sheets only when temperatures of $-13^{\circ} \mathrm{C}$ and warmer have been attained. If, as DiPrinzio, and others (2005) assert, migration recrystallization is evident by $200 \mathrm{~m}$ at Siple Dome, then such recrystallization must have occurred at appreciably colder temperatures than those observed in cores at Byrd and GISP2.

\section{Comparison studies of texture and fabrics in the Siple Dome core}

A comparison of results obtained by DiPrinzio and others (2005) with those presented here is revealing in that virtually identical profiles were observed with respect to fabrics but much less so in regard to the textural characteristics. As noted earlier, the DiPrinzio and others (2005) fabric and grain-size data were based on vertical thin-section analyses. The fabric data were subsequently rotated into the horizontal plane, thus allowing direct comparison with our datasets obtained almost entirely on measurements in horizontal thin sections. Though both profiles of grain-size change show similar trends, actual grain sizes measured by Di Prinzio and others (2005), when recalculated in terms of crystal cross-sectional areas, are found to be two to three times smaller than those measured here. Some of this discrepancy may be due to the different analytical techniques used to determine grain size. However, most of the observed differences in each of the grainsize profiles appear related to textural anisotropy intrinsic to vertical and horizontal sectioning. Variable layer structure, including the presence of fine-grained layers, is more likely to occur in vertical sections than in horizontal sections; this would favor the intersection, generally, of larger crystals in horizontal sections.
The overall nature of changes in the two fabric/texture profiles can be summarized as follows:

The fabric of ice between 60 and $100 \mathrm{~m}$ depth departs little from random, although definite signs of a nonrandom fabric are becoming apparent by $100 \mathrm{~m}$.

The transition to a broad vertical $c$-axis maximum is first evident at 99-100 m, an indication that directed stress has now begun to act on ice at Siple Dome. DiPrinzio and others (2005) estimate a total strain of about $20 \%$ at $200 \mathrm{~m}$; the broad vertical maximum persists to at least $240 \mathrm{~m}$, a fabric pattern that is consistent with uniaxial vertical compression.

A transition to a broadly dispersed girdle-like fabric occurs between 261 and $279 \mathrm{~m}$. $c$ axes tend to become less dispersed within the vertical plane of the girdle as the depth increases, a condition that persists to $686 \mathrm{~m}$. However, two modifications of the girdle-like fabric appear at intervals over the depth range $261-686 \mathrm{~m}$. The first involves a breakout of the girdle into several dispersed $c$-axis maxima, none of which coincide with the vertical axis of the core. The distribution of the maxima resembles the fabrics of dynamically recrystallized ice observed at other locations in Antarctica and Greenland. These modified fabrics are best exemplified in thin sections at 560 and $640 \mathrm{~m}$ in DiPrinzio and others (2005) and at 524 and $640 \mathrm{~m}$ in our studies.

A second modification involves a preferential clustering of $c$ axes about the vertical. Such strong clustering, indicative of shearing, is superimposed on the preexisting girdle. Examples of the two intermixed fabrics were observed at 261,341, 360 and $482 \mathrm{~m}$ in our study and at 339, 482 and $523 \mathrm{~m}$ in the DiPrinzio and others (2005) fabric profile. The vertical clustering of $c$ axes is invariably linked to layers of fine-grained ice, whereas ice exhibiting girdle-like fabrics is much coarser-grained. DiPrinzio and others (2005) attribute the formation of coarse-grained ice to recrystallization while simultaneously asserting that the layers of fine-grained ice have remained unrecrystallized.

The formation of strongly defined, great-circle girdles is generally ascribed to englacial deformation dominated by uniaxial longitudinal extension as exemplified by the fabrics and textures of ice at Vostok, Antarctica, (Lipenkov and others, 1989) and at NorthGRIP, Greenland (Wang and others, 2002). At Siple Dome, however, where the core was drilled just a few hundred meters from the dome's center, deformation in the top $60 \%$ of the ice is more likely to be dominated by uniaxial vertical compression than uniaxial longitudinal extension. However, an apparent mixing of two fabrics involving girdlelike features on the one hand and an increased vertical clustering of $c$ axes, indicative of shear in a plane normal to the $c$-axis cluster on the other hand, raises the question of whether two contrasted deformation states, represented by the girdle and point cluster fabrics respectively, can coexist in Siple Dome ice. Interestingly, Wang and others (2003) have also observed, in deeper ice at NorthGRIP, an increased vertical clustering of the $c$ axes superimposed upon the girdle, a situation very similar to the fabric pattern observed here and by DiPrinzio and others (2005). Wang and others (2003) attribute this 


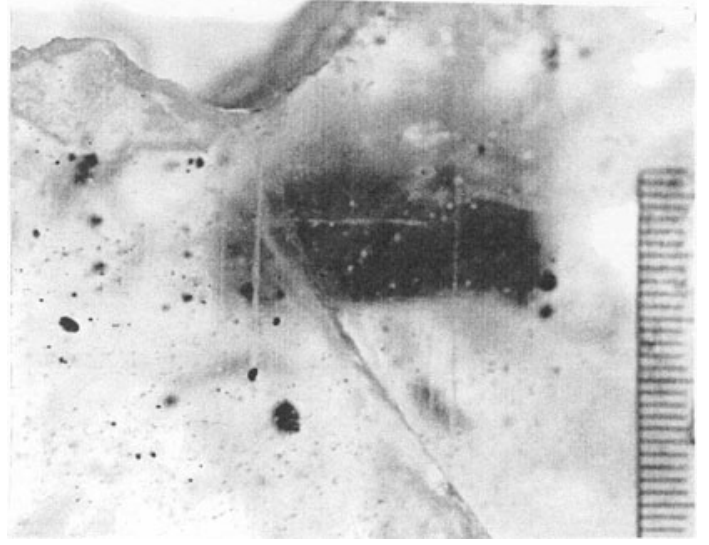

Fig. 7. Lithic fragment, oriented in the horizontal plane, located near the top of debris-bearing ice $2 \mathrm{~m}$ above bedrock at Siple Dome. Smallest scale subdivisions measure $1 \mathrm{~mm}$.

mixed fabric pattern to the combined effects of vertical compression and horizontal tension. However, the fabric pattern observed above may simply be a variation of an elongated $c$-axis maximum, unrelated to the existence of two contrasted deformation states. Support for this view is indicated in a study by Thorsteinsson (2002) who, on the basis of fabric development modeling, has shown that fabrics in which vertical clustering is superimposed on a vertical girdle are readily duplicated in the ice subjected to pure shear stress.

Somewhere between 686 and $703 \mathrm{~m}$ an abrupt change is observed in both fabric profiles, in which the dominantly girdle-like fabric above $686 \mathrm{~m}$ transitions into a very tight clustering of crystallographic $c$ axes about the vertical. This change to a shear-type fabric at $703 \mathrm{~m}$ persists to at least $790 \mathrm{~m}$ and is accompanied by an order-ofmagnitude reduction in grain size in both our and the DiPrinzio and others (2005) datasets.

A dramatic change back to very coarse-grained ice between 790 and $804 \mathrm{~m}$ occurs coincidentally with a significant change of fabric in which $c$ axes are now dispersed into several maxima, none of which is centered on the vertical. The temperature of the ice at $804 \mathrm{~m}$ is about $-9^{\circ} \mathrm{C}$ and the fabric is typical of ice that has undergone migration recrystallization. As indicated earlier, such recrystallization is normally observed at temperatures warmer than $-13^{\circ} \mathrm{C}$ in near-basal ice, for example, at Byrd Station (Gow and Williamson, 1976) and at GISP2 (Gow and others, 1997) and less certainly at GRIP (Thorsteinsson and others, 1997). However, below $848 \mathrm{~m}$ in both fabric profiles at Siple Dome there are too few crystals to obtain statistically significant fabrics, except to indicate continuation of the multi-maxima pattern of ice, subjected to migration recrystallization.

\section{SEDIMENT INCORPORATION AND GAS CONTENT OF BASAL ICE}

Lithic debris was first encountered at $1001.82 \mathrm{~m}$ depth, approximately $2 \mathrm{~m}$ above the glacier bed at Siple Dome. Entrained debris consisted mainly of widely dispersed particles in the silt-sand range. However, a singularly large tabular grain measuring $2.6 \mathrm{~cm} \times 1.0 \mathrm{~cm}$ and $0.5 \mathrm{~cm}$ thick,

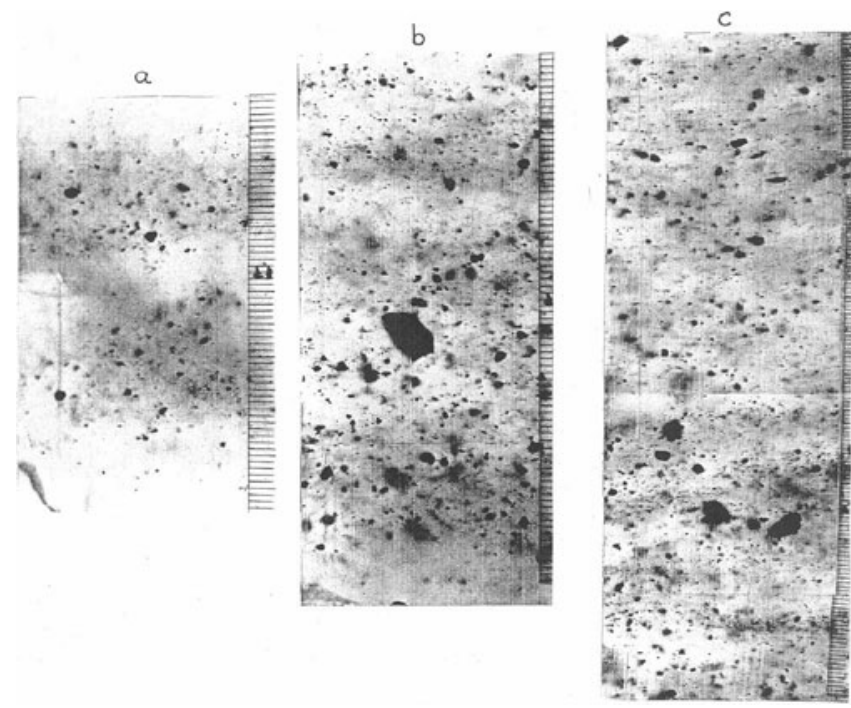

Fig. 8. Nature of debris entrainment in ice in cores from the bottommost ice at Siple Dome. Characteristic features included layers of dispersed debris between layers of debris-free ice $(a, b)$ and a sustained sequence of debris-bearing ice (c). Smallest scale subdivisions measure $1 \mathrm{~m}$.

oriented in the horizontal plane, was observed near the top of the transition between bubbly glacier ice and the debrisbearing basal ice (Fig. 7). Examples of the dispersed nature of sediment incorporation in Siple Dome basal ice are given in Figure 8.

The basal ice at Siple Dome contained none of the coarser-grained debris such as cobbles and boulders that occurred sporadically in the basal ice at Byrd, located about $500 \mathrm{~km}$ upstream of Siple Dome. Furthermore, the debris entrained in ice at Byrd was strongly stratified throughout and consisted predominantly of clay, sand and pebble-sized particles in addition to the aforementioned cobbles and boulders (Gow and others, 1979). Most of the particles identified as pebbles in the Byrd core actually consisted of sedimentary aggregates composed of clay, silt and sand that disintegrated upon melting. Similarly it was found that many of the sand-sized particles entrained in the basal ice at Siple Dome were also composed of frozen aggregates of silt and clay.

Results of debris concentration measurements of eight samples from the basal ice at Siple Dome together with measurements of their total gas content are presented in Table 2. Additionally, analyses of total gas content were performed on five bubbly glacial ice samples from directly above the transition with the debris-bearing basal ice. Total gas content was measured using a technique described by Langway (1958a) in which gas evolved during the complete melting, under kerosene, of accurately weighed ice samples is collected in a burette. Sediment released when ice samples were melted was oven-dried and weighed to determine debris concentrations.

Debris concentration in the basal ice at Siple Dome ranged from $0.01 \%$ to $1.08 \%$ by weight. These sediment loads are between one and two orders of magnitude smaller than the $12-15 \%$ by weight of debris entrained in basal ice cores at Byrd (Gow and others, 1979); they clearly reflect major differences in the textural characteristics and debris concentrations in basal ice at these two locations. An 
examination of Table 2 suggests a moderate level of correlation between increased debris concentration and decreased total gas content.

According to Engelhardt (2004), the ice at Siple Dome is frozen to its bed at a temperature of $-2.54^{\circ} \mathrm{C}$, about $1.9^{\circ} \mathrm{C}$ lower than the estimated pressure-melting point. With the basal ice temperature so close to pressure melting, the question becomes: how and when was debris incorporated into the ice? In the particular case of debris entrapment in basal ice at Byrd Station, Gow and others (1979) concluded that this occurred simultaneously with a process of 'freezeon' of glacially derived meltwater at the bed. A critical observation was the absence of gas in the basal ice at Byrd, which Gow and others (1979) have suggested may well constitute the single most diagnostic test for discriminating between debris entrained in the melt-refreeze process and debris incorporated by purely mechanical means (e.g. shearing). At Byrd in 1968, water was encountered after the drill had penetrated the bed. This clearly demonstrated that at that time melting of the basal ice was occurring at the bed.

A case for meltwater refreezing at the bed at Siple Dome certainly applies to the two bottommost samples of ice tested for total gas content, which is likely to be much less than indicated in Table 2. In these two samples, maximum dissolution of gas in the meltwater was assumed. However, only occasional bubbles were observed entering the burette during melting of these two samples, indicating that minimal dissolution of gas in the meltwater had actually occurred. Except for the sample from 1002.09-1002.13 m which was bubble-free and exhibited a low total gas content, all the remaining debris-bearing samples were obtained from moderately bubbly ice that also yielded moderate to elevated gas concentrations when melted. Enhanced gas concentrations listed in Table 1 are still appreciably lower than those of the air-rich glacial ice located above the transition to debris-bearing basal ice. Total gas contents of up to $4 \mathrm{~mL}$ per $100 \mathrm{~g}$ ice can occur when water is frozen rapidly. If the saturation level for gas dissolved in the water is exceeded, bubbles begin to nucleate at the freezing interface and become entrained in the ice as freezing proceeds. Such a process could explain the origin of the widespread occurrence of bubbles in the ice with moderate gas concentrations. Downward diffusion of gas from the overlying air-rich glacial ice could also have contributed to moderate gas concentrations in basal ice at Siple Dome. While advocating freeze-on as the dominant mechanism of debris incorporation in basal ice at Camp Century, Greenland, Herron and Langway (1979) have suggested that downward diffusion of air from bubble-rich glacial ice has also led to moderate gas concentrations similar to those observed in basal ice at Siple Dome.

As indicated above, the ice at Siple Dome is still frozen to its bed. While evidence to account for the incorporation of debris in basal ice at Siple Dome is best explained in terms of a freeze-on process, we have no way of determining just when ice at the bed attained the pressure-melting point or for how long this condition persisted before freeze-on of meltwater occurred to allow $2 \mathrm{~m}$ of debris-bearing ice to be accreted.

\section{CONCLUSIONS}

The quality of the ice cores drilled at Siple Dome varied from good to excellent in the top $350 \mathrm{~m}$. However, fracturing of the core increased in severity between $400 \mathrm{~m}$ and the
Table 2. Siple Dome basal ice samples

\begin{tabular}{ccc}
\hline Depth range & Entrained debris & $\begin{array}{c}\text { Gas content } \\
\mathrm{m}\end{array}$ \\
& $\mathrm{wt} \%$ & $\mathrm{~mL}(100 \mathrm{~g})^{-1}$ at STP \\
\hline $995.80-995.85$ & - & 11.56 \\
$997.53-997.58$ & - & 11.38 \\
$998.11-998.16$ & - & 10.61 \\
$1000.06-1000.11$ & - & 11.46 \\
$1000.64-1000.69$ & - & 10.23 \\
$1001.85-1001.90$ & 0.19 & 8.18 \\
$1002.09-1002.13$ & 1.08 & 2.83 \\
$1002.55-1002.60$ & 0.71 & 4.97 \\
$1002.77-1002.82$ & 0.10 & 7.28 \\
$1003.03-1003.08$ & 0.16 & 6.75 \\
$1003.68-1003.73$ & 1.06 & 2.12 \\
$1003.73-1003.78$ & 0.38 & 1.46 \\
\hline
\end{tabular}

*Standard temperature and pressure.

bottom of the ice dome at $1004 \mathrm{~m}$ depth. This interval of core constitutes the brittle zone in which bubbly ice persists without break to the ice-rock interface. Melt layers were observed sporadically throughout the core as were inclined layers. Decreasing concentrations of air bubbles below $600 \mathrm{~m}$ are attributed to gas hydrate formation. Cores from the brittle zone at Siple Dome, unlike other deep cores from Antarctica and Greenland, have undergone minimal relaxation and have remained brittle and prone to fracturing during processing more than 5 years after they were drilled. This behavior is attributed to the existence of unrelieved residual stresses possibly related to the intimate contact of Siple Dome with Kamb and Bindschadler Ice Streams located on either side of the dome.

Structurally the Siple Dome ice core is characterized by extensive recrystallization, including a progressive increase in the size of crystals in the upper levels of the ice. This crystal growth was accompanied by development of a fabric favoring a broad clustering of crystallographic $c$ axes about the vertical, consistent with the rotation of $c$ axes toward the axis of vertical compression. Beginning at about $261 \mathrm{~m}$, a change in $c$-axis orientation toward a vertical girdle-like fabric began to appear and by $360 \mathrm{~m}$ had become fully established; its formation is attributed to the ice undergoing uniaxial longitudinal extension. This girdle-like fabric generally persisted to about $686 \mathrm{~m}$, though in most thin sections the girdle was somewhat incomplete and in a number of cases was replaced by three or four discrete maxima, possibly indicative of migration recrystallization. Between 686 and $703 \mathrm{~m}$ a very abrupt change in $c$-axis fabric, that persisted to around $800 \mathrm{~m}$ depth, occurred coincidentally with sustained deposition of volcanic ash. The fabric, characterized by a very tight clustering of the $c$ axes about the vertical axis of the core, and accompanied by an orderof-magnitude reduction in the size of the crystals, is attributed to deformation dominated by strong horizontal shear. It is speculated that this formation of a shear fabric between 700 and $800 \mathrm{~m}$ is linked to enhanced concentrations of silt-sized volcanic particles affecting the rheological properties of the ice. In ice below $800 \mathrm{~m}$ and within $2 \mathrm{~m}$ of the bed, the $c$-axis fabric had converted entirely to a multi-maximum orientation, composed of very large crystals with dimensions often exceeding the diameter of the core. 
The bottom $2 \mathrm{~m}$ of ice at Siple Dome contained widely dispersed sediment, principally in the silt-sand particle size range. Its occurrence is attributed to past accretion by freeze-on of basal meltwater. Currently the basal ice is frozen to the bed at $-2.54^{\circ} \mathrm{C}$.

\section{ACKNOWLEDGEMENTS}

This research was funded by the Office of Polar Programs, US National Science Foundation under grant OPP-0126212. Additional financial support was provided by the US Cold Regions Research and Engineering Laboratory. We thank B. Elder of the US Army Engineer Research and Development Centre-US Army Cold Regions Research and Engineering Laboratory (ERDC-CRREL) and the curatorial staff of the US National Ice Core Laboratory for their help in processing the Siple Dome ice core. Logistical support was provided by Antarctic Support Associates/Raytheon Polar Service Company and the New York Air National Guard. The authors also thank an anonymous reviewer for some very insightful comments.

\section{REFERENCES}

Alley, R.B. 1988. Fabrics in polar ice sheets: development and prediction. Science, 240(4851), 493-495.

Alley, R.B. and I.M. Whillans. 1991. Changes in the West Antarctic ice sheet. Science, 254(5034), 959-963.

Alley, R.B., A.J. Gow, S.J. Johnsen, J. Kipfstuhl, D.A. Meese and T. Thorsteinsson. 1995. Comparison of deep ice cores. Nature, 373(6513), 393-394.

Azuma, N. and A. Higashi. 1985. Formation processes of ice fabric pattern in ice sheets. Ann. Glaciol., 6, 130-134.

Azuma, N. and 6 others. 1999. Textures and fabrics in the Dome F (Antarctica) ice core. Ann. Glaciol., 29, 163-168.

Butkovich, T.R. 1953. Density of single crystals of ice from a temperate glacier. SIPRE Res. Pap. 7.

Dansgaard, W. and 6 others. 1982. A new Greenland deep ice core. Science, 218(4579), 1273-1277.

Das, S.B. 2003. West Antarctic ice sheet surface melting and Holocene climate variability. (PhD thesis, The Pennsylvania State University.)

Das, S.B. and R.B. Alley. 2005. Characterization and formation of melt-layer in polar snow: observation and experiments from West Antarctica. J. Glaciol., 51(173), 307-313.

De La Chapelle, S., O. Castelnau, V. Lipenkov and P. Duval. 1998. Dynamic recrystallization and texture development in ice as revealed by the study of deep ice cores in Antarctica and Greenland. J. Geophys. Res., 103(B3), 5091-5105.

DiPrinzio, C.L., L.A. Wilen, R.B. Alley, J.J. Fitzpatrick, M.K. Spencer and A.J. Gow. 2005. Fabric and texture at Siple Dome, Antarctica. J. Glaciol., 51(173), 281-290.

Duval, P. and O. Castelnau. 1995. Dynamic recrystallization of ice in polar ice sheets. J. Phys. IV [Paris], 5, 197-205. (Supplément au 3.)

Engelhardt, H. 2004. Ice temperature and high geothermal flux at Siple Dome, West Antarctica, from borehole measurements. J. Glaciol., 50(169), 251-256.

Fujita, S., M. Nakawo and S. Mae. 1987. Orientation of the 700-m Mizuho core and its strain history. Proc. NIPR Symp. Polar Meteorol. Glaciol., 1, 122-131.

Gow, A.J. 1968. Deep core studies of the accumulation and densification of snow at Byrd Station and Little America V, Antarctica. CRREL Res. Rep. 197.

Gow, A.J. 1970. Deep core studies of the crystal structure and fabrics of Antarctic glacier ice. CRREL Res. Rep. 282
Gow, A.J. 1971. Relaxation of ice in deep drill cores from Antarctica. J. Geophys. Res., 76(11), 2533-2541.

Gow, A.J. and H. Engelhardt. 2000. Preliminary analysis of ice cores from Siple Dome, West Antarctica. In Hondoh, T., ed. Physics of ice core records. Sapporo, Hokkaido University Press, 63-82.

Gow, A.J. and D.A. Meese. 2007. The distribution and timing of tephra deposition at Siple Dome, Antarctica: possible climatic and rheologic implications. J. Glaciol., 53(183), 585-596.

Gow, A.J. and T. Williamson. 1971. Volcanic ash in the Antarctic ice sheet and its possible climatic implications. Earth Planet. Sci. Lett., 13(1), 210-218.

Gow, A.J. and T. Williamson. 1976. Rheological implications of the internal structure and crystal fabrics of the West Antarctic ice sheet as revealed by deep core drilling at Byrd Station. Geol. Soc. Am. Bull., 87(12), 1665-1677.

Gow, A.J., S. Epstein and W. Sheehy. 1979. On the origin of stratified debris in ice cores from the bottom of the Antarctic ice sheet. J. Glaciol., 23(89), 185-192.

Gow, A.J., D.A. Meese and R.A. Alley. 1993. Discontinuities including possible distortion of the environmental record in cores of deep basal ice from central Greenland. Eos, 74(43), 84

Gow, A.J. and 6 others. 1997. Physical and structural properties of the Greenland Ice Sheet Project 2 ice cores: a review. J. Geophys. Res., 102(C12), 26,559-26,575.

Herron, S. and C.C. Langway, Jr. 1979. The debris-laden ice at the bottom of the Greenland ice sheet. J. Glaciol., 23(89), 193-207.

Langway, C.C., Jr. 1958a. Bubble pressures in Greenland glacier ice. IASH Publ. 47 (Symposium at Chamonix 1958 - Physics of the Movement of Ice), 336-349.

Langway, C.C., Jr. 1958b. Ice fabrics and the universal stage. SIPRE Tech. Rep. 62

Lipenkov, V.Ya., N.I. Barkov, P. Duval and P. Pimienta. 1989 Crystalline texture of the $2083 \mathrm{~m}$ ice core at Vostok Station, Antarctica. J. Glaciol., 35(121), 392-398.

Nereson, N.A., E.D. Waddington, C.F. Raymond and H.P. Jacobson. 1996. Predicted age-depth scales for Siple Dome and inland WAIS ice cores in West Antarctica. Geophys. Res. Lett., 23(22), 3163-3166.

Paterson, W.S.B. 1994. The physics of glaciers. Third edition. Oxford, etc., Elsevier.

Rigsby, G.P. 1955. Study of ice fabrics, Thule area, Greenland. SIPRE Res. Rep. 26, 1-6.

Rigsby, G.P. 1960. Crystal orientation in glacier and experimentally deformed ice. J. Glaciol., 3(27), 589-606.

Robin, G. deQ. 1983. The climatic record in polar ice sheets. Cambridge, etc., Cambridge University Press.

Taylor, K.C. and 9 others. 1993. Electrical conductivity measurements from the GISP2 and GRIP Greenland ice cores. Nature, 366(6455), 549-552.

Thorsteinsson, T. 2002. Fabric development with nearest-neighbor interaction and dynamic recrystallization. J. Geophys. Res., 107(B1), 2014. (10.1019/2001JB000244.

Thorsteinsson, T., J. Kipfstuhl and H. Miller. 1997. Textures and fabrics in the GRIP ice core. J. Geophys. Res., 102(C12), 26,583-26,599.

Wang, Y. and N. Azuma. 1999. A new automatic ice-fabric analyzer which uses image-analysis techniques. Ann. Glaciol., 29, 155-162.

Wang, Y., T. Thorsteinsson, J. Kipfstuhl, H. Miller, D. Dahl-Jensen and H. Shoji. 2002. A vertical girdle fabric in the NorthGRIP deep ice core, North Greenland. Ann. Glaciol., 35, 515-520.

Wang, Y., S. Kipfstuhl, N. Azuma, T. Thorsteinsson and H. Miller 2003. Ice fabrics study in the upper $1500 \mathrm{~m}$ of the Dome $\mathrm{C}$ (East Antarctica) deep ice core. Ann. Glaciol., 37, 97-104.

Wilen, L.A. 2000. A new technique for ice-fabric analysis. J. Glaciol., 46(152), 129-139.

Wilen, L.A., C.L. DiPrinzio, R.B. Alley and N. Azuma. 2003. Development, principles, and applications of automated ice fabric analyzers. Microsc. Res. Tech., 62(1), 2-18. 